\title{
Novel Genetic Diversity Through Somatic Mutations: Fuel for Adaptation of Reef Corals?
}

\section{Madeleine J. H. van Oppen ${ }^{1, *}$, Petra Souter ${ }^{1}$, Emily J. Howells ${ }^{1,2,3,4}$, Andrew Heyward ${ }^{5}$ and Ray Berkelmans ${ }^{1}$}

1 Australian Institute of Marine Science, PMB 3, Townville MC, Queensland 4810, Australia; E-Mails: m.vanoppen@aims.gov.au (M.J.H.O.); p.souter@aims.gov.au (P.S.); em.howells@gmail.com (E.J.H.); r.berkelmans@aims.gov.au (R.B.)

2 School of Marine and Tropical Biology, James Cook University, Townsville, Queensland 4814, Australia

3 Australian Research Council Centre of Excellence for Coral Reef Studies, James Cook University, Townsville, Queensland 4814, Australia

4 AIMS@JCU, Australian Institute of Marine Science, School of Marine and Tropical Biology, James Cook University, Townsville, Queensland 4814, Australia

5 Australian Institute of Marine Science, UWA Oceans Institute (M096), 35 Stirling Highway, Crawley, Western Australia 6009, Australia; E-Mail: a.heyward@aims.gov.au

* Author to whom correspondence should be addressed; E-Mail: m.vanoppen@aims.gov.au; Tel.: +61-7-47534370; Fax: +61-7-47725852.

Received: 15 June 2011; in revised form: 26 July 2011/ Accepted: 27 July 2011/

Published: 12 August 2011

\begin{abstract}
Adaptation of reef corals to climate change is an issue of much debate, and often viewed as too slow a process to be of relevance over decadal time scales. This notion is based on the long sexual generation times typical for some coral species. However, the importance of somatic mutations during asexual reproduction and growth on evolution and adaptation (i.e., cell lineage selection) is rarely considered. Here we review the existing literature on cell lineage selection and show that the scope for somatic mutations to arise in the coral animal and associated Symbiodinium is large. For example, we estimate that $\sim 100$ million somatic mutations can arise within a branching Acropora coral colony of average size. Similarly, the large population sizes and rapid turn-over times of in hospite Symbiodinium likely result in considerable numbers of somatic mutations. While the fate of
\end{abstract}


new mutations depends on many factors, including ploidy level and force and direction of selection, we argue that they likely play a key role in the evolution of reef corals.

Keywords: coral; Symbiodinium; adaptation; somatic mutations; cell lineage selection; climate change

\section{Introduction}

The speed at which our climate is changing is unprecedented in the past 50 million years [1]. Of particular concern to reef corals are the increase in seawater temperature and lowering of seawater $\mathrm{pH}$ (acidification). Corals are sensitive to even small temperature elevations beyond the norm, which can lead to a break-down of the obligate symbiosis between the coral animal and its algal endosymbionts (unicellular dinoflagellates of the genus Symbiodinium, also known as zooxanthellae) (Figure 1). This results in a paling of the coral tissues due to loss of Symbiodinium cells and/or their pigments and is therefore referred to as coral bleaching. During unusually warm summers, bleaching events often extend across many reefs and reef systems. Such mass bleaching events can severely affect many coral species and can cause considerable coral mortality. Ocean acidification, through dissolution of elevated atmospheric $\mathrm{CO}_{2}$ into the seawater, is likely to affect calcification, reducing skeletal extension rates (i.e., growth rates) and skeletal density, as well as the corals' productivity [2]. These deleterious effects may further compound each other, as corals show increased sensitivity to temperature under high $\mathrm{CO}_{2}$ levels [3]. On a world-wide scale, contemporary coral reefs have suffered large declines in coral cover [4,5] (see [6] for data on some regional patterns) and $\sim 15 \%$ of the world's coral reefs are seriously threatened with complete loss within the next 10-20 years [7]. These observations indicate that unless corals can adapt, further loss of coral cover and diversity is expected to occur over the next decades.

Figure 1. Close-up photograph of a polyp of the coral species Acropora tenuis showing Symbiodinium inside the tentacle tissues. Carbon fixed by Symbiodinium photosynthesis is the primary source of nutrition in most corals. Photo credit: Jean-Baptiste Raina.

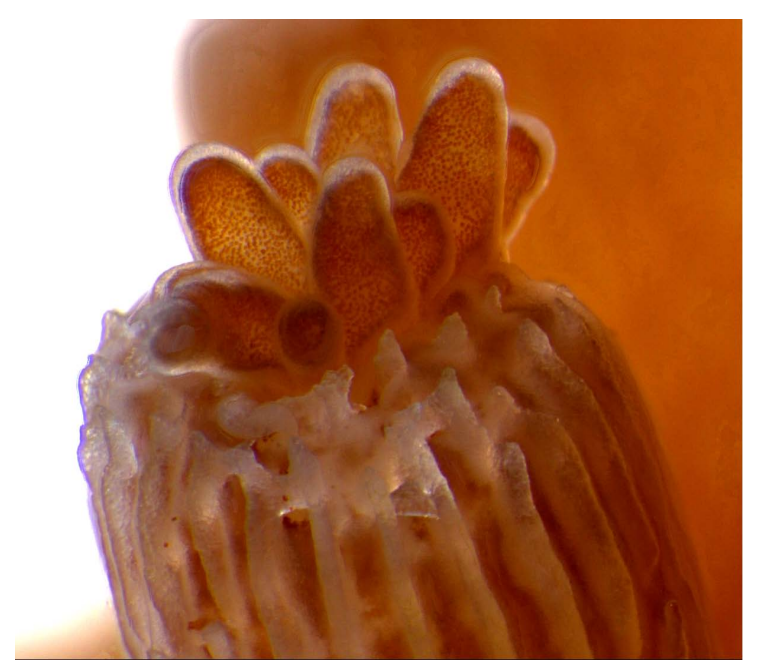


It has been claimed that the rate of adaptation of the coral animal is too slow to keep up with the predicted pace of warming and ocean acidification [8,9] due to the long sexual generation times (i.e., the average age at which sexual offspring is produced) of corals (see [10,11] for alternative opinions). Some coral species do indeed have long sexual generation times of $>30$ years, but many common and abundant corals, such as species of Acropora and Pocillopora, mature early (from $\sim 4 \mathrm{yr}$ of age [12,13]). This 'slow adaptation' hypothesis in corals considers adaptation solely as the result of selection on standing genetic variation from one sexual generation to the next. Corals possess attributes that may warrant more complex models of adaptation via selection on cells with different genotypes arising through somatic mutation (i.e., mosaicism) and their evolutionary role through both asexual and sexual reproduction. Furthermore, the physiological tolerances of corals, including thermal tolerance, are strongly influenced by their Symbiodinium partners [14-17], which are therefore likely to be subject to strong selective pressures under climate change. In hospite populations of Symbiodinium are likely haploid [18,19] and maintained asexually; sexual reproduction has never been observed [20,21]. Non-neutral somatic mutations in Symbiodinium arising in hospite are subject to selection and if the mutation is beneficial, the new mutant can theoretically displace most if not all of the original genotype(s) within the coral colony (Figure 2), as has been shown in several free-living microalgae when exposed to extreme toxicity [22,23]. Somatic mutations and selective sweeps in non-eukaryotic microbes associated with corals may also play a role in their adaptation to climate change. These organisms are not specifically addressed here, although what we discuss applies to them also [24]. The role of somatic mutations in adaptation of the coral animal was first considered by Fautin [25] and Buddemeier et al. [26] and those in the associated Symbiodinium by Correa and Baker [24]. The ideas of these authors are expanded upon here, and we argue that evolution within mitotic cell lineages of both the coral host and its associated Symbiodinium, also known as cell-lineage selection, may play a role in the adaptation of corals to climate change. This warrants testing via robust scientific experimentation.

Figure 2. Cartoon of the spread of a beneficial mutation in a Symbiodinium community in hospite. The white and blue circles represent two wild-type Symbiodinium types, the white circles with a black border represent mutant Symbiodinium cells which have evolved from the white type. The mutant cells are under positive selection and increase their relative abundance over time (from left to right).

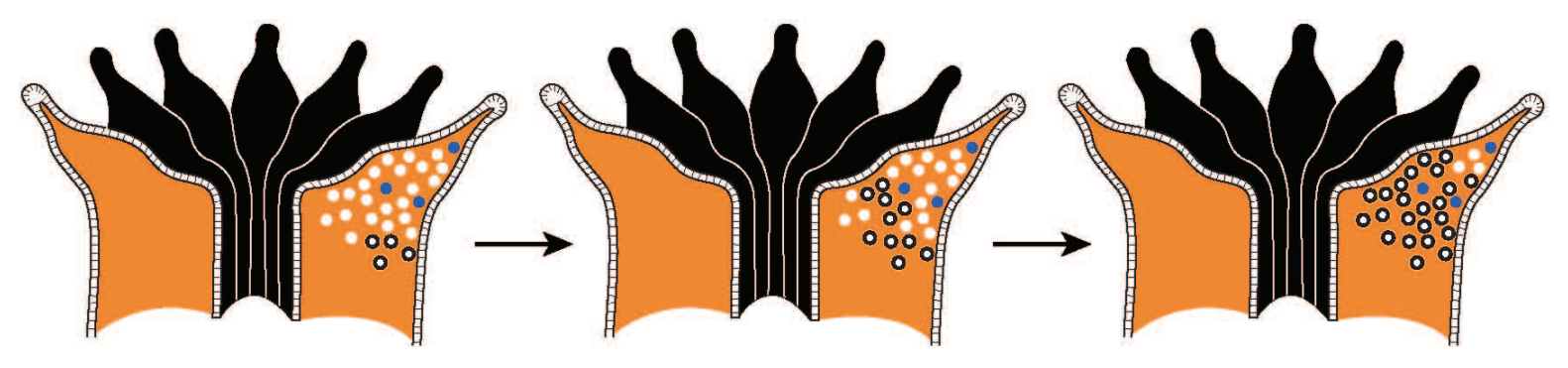

\section{Somatic Mutations}

Somatic mutation rates are consistently greater than germ line mutation rates, both on a per cell division basis as well as on a per sexual generation basis [27]. For example, tissue assays of mouse and 
rat show that somatic cells accumulate two- to six-fold more mutations than germ cells in the testes by the time of sexual maturity, and in humans the average mutation rate in four somatic cell types is 17 times higher than in the germ line [27]. In organisms that reproduce sexually and where the differentiation between somatic and germ line cells (i.e., germ line cell sequestration) occurs early in ontogeny, a clear evolutionary difference exists between a somatic and a germ line mutation. The former is mostly not heritable (unless the mutation arises during the first few cell divisions prior to germ line cell sequestration) and hence has no impact on the fitness of future generations. In contrast, corals and many other modular marine invertebrates, as well as many plants, lack segregation of germ line and somatic cells $[25,28]$. In these organisms, germ cell differentiation occurs continuously from somatic stem cells, resulting in a higher probability of somatic mutations becoming incorporated in gametes of corals than in those of organisms with germ-soma segregation. This means that somatic mutations that have a fitness effect can provide a substrate for selection and form the basis of adaptation. In humans, for instance, the number of cell divisions from the fertilized egg to formation of the female gamete is only $\sim 24$ [29]. Sperm produced in adolescents at the age of 13 has undergone $\sim 36$ cell divisions, followed by $\sim 23$ cell divisions per year [29]. Yet in corals, innumerable cell divisions occur before gametes are formed from somatic cells, both over the life time of a coral colony and between episodes of sexual reproduction (which is typically a year in broadcast spawning corals). In essence, mutant cell lineages that arise though somatic mutations are legitimate units of selection, either where a somatic cell lineage undergoes a large number of divisions before becoming a germ cell or through asexual reproduction by fragmentation, budding or other means (see below) [30]. Thus, in corals, not only gametic mutations, but also somatic mutations can eventually be represented in gametes and hence can be passed on to the next generation.

\section{Evolution through Cell Lineage Selection in Organisms Other Than Corals}

The importance of somatic mutations in evolution and adaptation is well recognized for some organisms and life forms, such as prokaryotes and viruses (reviewed in [31]), but is often ignored in eukaryotic taxa (except for plants [32-35]). In the absence of sexual reproduction, novel genetic variation can only arise through somatic mutations. Asexuality is found in over half of all eukaryotic phyla [28,33]; many higher plants, algae and animals are exclusively or largely clonal, including a range of species of aphids, cladocerans, freshwater snails, bryozoans and corals (reviewed in [36]). Some asexual animal species are believed to be ancient, including darwinulid ostracods (100 Myr) [37], the brine shrimp Artemia salina (30 Myr) [38], bdelloid rotifers (at least 35-40 Myr) [39,40], the weevil, Aramigus tessellates (2 Myr) [41] and salamanders of the genus Ambystoma ( 4-5 Myr) [42]. These organisms have evolved through somatic mutation and selection in the absence of sex. In support of this notion, variance in many anatomical traits, karyotype, genetic markers and fecundity have been observed in natural populations of asexual aphid species (reviewed in [43]). Furthermore, cell lineage selection was observed in asexual (apomictic) peach potato aphids, which led to an approximately 30-fold increase in the level of esterase production (which confers resistance to pesticides) after only 14 asexual generations under laboratory selection [44]. Intra-clonal heritable genetic variation is also present in the red seaweed species Asparagopsis armata and Delisea pulchra [32], and significant responses to cell lineage selection have been documented in the former [35]. Moreover, 
somatic mutations have been documented in long-lived trees $[45,46]$, and many plants with long sexual generation times are well able to keep up the arms race with their short-lived pests [36], which provides further evidence that evolution can be fast in organisms with infrequent sexual reproduction. Microalgae, including dinoflagellates, undergo spontaneous genetic mutations in culture at a detectable rate, some of which are under positive selection. For example, genetic adaptation to increased nutrients and temperature was demonstrated in the asexually growing dinoflagellate Prorocentrum triestinum [47]. The chlorophycean, Scenedesmus intermedius, showed the occurrence of beneficial spontaneous mutations at the rate of $2.12 \times 10^{-5}$ mutants per mitotic cell division when grown under stress from acid wastes rich in heavy metals/metalloids [22]. The chlorophycean Dictyosphaerium chlorelloides produced mutants resistant to various environmental stressors, including low $\mathrm{pH}$, trinitrotoluene, and heavy metals, at a rate of $\sim 1 \times 10^{-5}$ to $\sim 1 \times 10^{-7}$ per cell per asexual generation (i.e., per cell division) [23,48-50]. The studies listed are only a small subset of the many known examples of detectable somatic mutations and the evolution through selection on somatic mutations, but demonstrate that evolution occurs and can be fast in the absence of sex.

\section{Asexuality in Corals and Their Associated Symbiodinium}

Asexual reproduction is a key attribute of colonial corals that may facilitate the proliferation of localized mutations within colonies and subsequent propagation as new independent colonies. A number of modes of asexual reproduction are recognized in reef building corals [51-54]. Growth within colonies typically requires production of the modular polyp units via extratentacular budding (polyps forming from tissues adjacent to or in between existing polyps), or intratentacular budding (polyps forming by internal division of existing polyps). Subsets of these polyps can further proliferate into distinct colonies via fragmentation (portions of the colony becoming physically separated from the rest of the colony). In branching corals, where new branches originate through the budding of single apical polyps from radial polyps, fragmentation can be the dominant mode of colony propagation [55]. This mode of asexual reproduction has also been documented in massive species [56]. Other less well known forms of asexual reproduction in reef building corals include transverse division (polyps forming within the tentacular ring, also known as "strobilation"; reviewed by [52]), asexual planulae (planulae genetically identical to parent polyps, exhibited by Pocillopora damicornis, several species of Tubastrea and Oulastrea crispata; reviewed by [54]), polyp extrusions (extensions of tissue which flow out from corallites and attach to the substrate, exhibited by at least 20 species in nine families, including Acroporidae, Faviidae, Pocilloporidae and Agariciidae; reviewed by [53]), polyp bailout (expulsion or detachment and relocation of individual polyps from the skeleton, often due to stress, exhibited by several pocilloporids, Acropora sp., Euphillia sp., Favia favus and Oculia Patagonia [53,55,57]), and polyp balls (growth of round protrusions of polyps and skeleton on the surface or margins of some Goniopora and faviid species $[53,58]$ ). Almost all these modes of asexual reproduction result from a single polyp, making the propagation of a somatic mutation in one polyp into a whole new colony a distinct possibility (Figure 3C, 3D). The diversity of sexual and asexual reproductive modes displayed by corals may provide them with adaptive mechanisms similar to those in some plants, where mosaicism can play a significant role in adaptation [59]. In some species, such as the massive Porites, individual colonies can live and reproduce for centuries, growing indeterminately 
through asexual budding, and consequently producing large colonies of several million polyps. In such long lived species, there is a high probability that somatic mutations will be preserved and accumulate over time.

Knowledge of key aspects of new polyp formation relevant to cell lineage selection in cnidarians is derived from pioneering work conducted on the non-colonial model coelenterate Hydra. In the early twentieth century, Tannreuther [60] described in detail how new buds commence with an increase in volume and division of cells in the wall of the parent Hydra. Once these cells have increased in volume once or twice, the ectoderm bulges out. Cells in this bulge become differentiated into two regions: the central part which becomes the distal end of the new polyp where cells become dormant and the region on either side in which the cells divide rapidly and contribute almost entirely to the growth of the bud (Figure 3A). Since only one or two cells on either side of the distal end of the bud are involved in growth, any mutation within these cells has a high probability of making up the majority of the new polyp. More recently, it has been shown that in addition to the involvement of cells at the site formation of the new bud, endodermal cell motility can be involved in bud formation [61,62]. Transgenic cells expressing a green fluorescent protein were observed to migrate to distant sites within the polyp (including the site of formation of the new bud), and oriented cell division of the transgenic cells occurred during the migration process [61]. Thus, not only mutant cells at the site of polyp formation but also mutant cells arisen elsewhere in the body may be incorporated in the newly budded polyp (Figure 3B) [63].

Corals acquire Symbiodinium either from the environment as larvae or primary polyps ( $\sim 85 \%$ of species [64]) or via parental transmission to eggs, larvae or asexual propagules. Symbiodinium cells occupy vacuoles within the coral gastroderm, maintaining large population sizes in the order of $10^{6}$ cells per $\mathrm{cm}^{2}$ of coral tissue, which vary in healthy coral symbioses from 0.5 to $9 \times 10^{6}$ cells per $\mathrm{cm}^{2}$ among species [65,66] and in response to environmental parameters [67-71]. Symbiodinium also form symbioses with other invertebrate and protist hosts (reviewed in [72]) and occur free-living in various habitats including reef sediments $\left(>10^{3}\right.$ cells per $\left.\mathrm{cm}^{3}\right)$, seawater $\left(\sim 10^{2}\right.$ cells per $\left.\mathrm{cm}^{3}\right)$ [73] and the surface of benthic macroalgae [74,75]. Populations are maintained by binary fission and it is not known whether sexual reproduction exists within the Symbiodinium life cycle [76]. Symbiodinium cells in the process of dividing account for 0.4 to $12 \%$ of the in hospite population [77-79] corresponding to asexual generation (i.e., doubling) times of three to 74 days, with $\sim$ seven days being common in most corals [79]. Symbiodinium growth is inversely related to density, with the fastest rates observed in new host tissue (e.g., the tips of coral branches [79]) and in the re-population of bleached tissue [80,81]. Growth is regulated by the rate of carbon fixation and utilization $[82,83]$ and the amount of nutrients provided by the host $[84,85]$, with further regulation of population sizes in hospite by host digestion and extrusion of Symbiodinium cells $[85,86]$. In free-living habitats, growth rates of Symbiodinium are not known, but doubling times in the order of days to weeks have been recorded for other species of free-living dinoflagellates [79]. In culture, Symbiodinium are capable of rapid growth with typical doubling times of less than 3 days [87-89], although some strains grow more slowly [90]. The asexual mode of reproduction and large in hospite population sizes suggest that somatic mutations are likely to be an important source of novel genetic variation for Symbiodinium. The fitness effects of mutations are generally more rapidly expressed in haploid organisms, such as Symbiodinium, as the impact of the 
mutation is not confounded by the wild-type allele on the homologous chromosome as is the case in diploid organisms (i.e., heterozygous state).

Figure 3. Cartoon showing several ways in which mutant cells (shown in blue) can spread in corals. (A) Coral polyp with a mutation arisen in a cell of the endodermis (=gastrodermis) at the site of new polyp formation. As the budding process progresses, the mutated cell divides to form a mutant cell lineage which constitutes the endoderm of the newly budded polyp; (B) Mutant cells arisen in the upper part of the coral polyp migrate to some of the polyp's tentacles as well as into the budding polyp. As the budding process progresses, most of the endodermal cells of the newly budded polyp are of the mutant genotype; (C) Massive coral colony in which a mutation has arisen and spreads as the colony grows. At some point in time, partial colony mortality divides the colony into two physically separated units that are of different genotypes (wild-type and mutant); and (D) Branching coral in which a mutated branch breaks off and re-establishes itself by attachment to the substratum. The wild-type 'mother' colony produces wild-type gametes only, while the mutant colony produces both wild-type and mutant gametes as corals are diploid [63] and only half of the gametes in a heterozygous individual will carry the mutation following meiosis.

A.

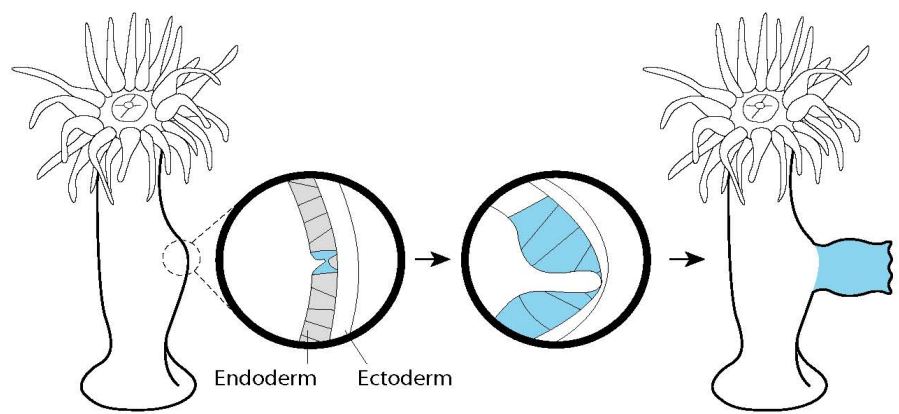

B.

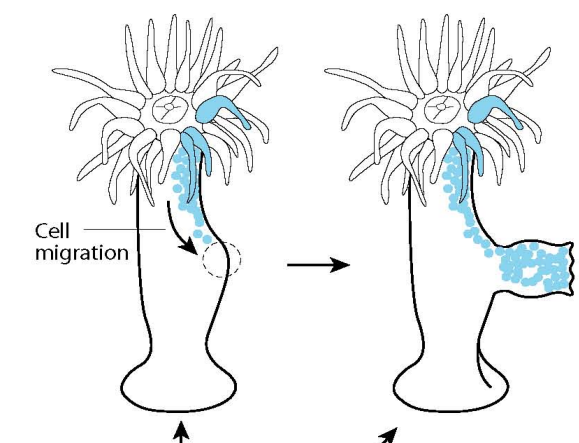

c.

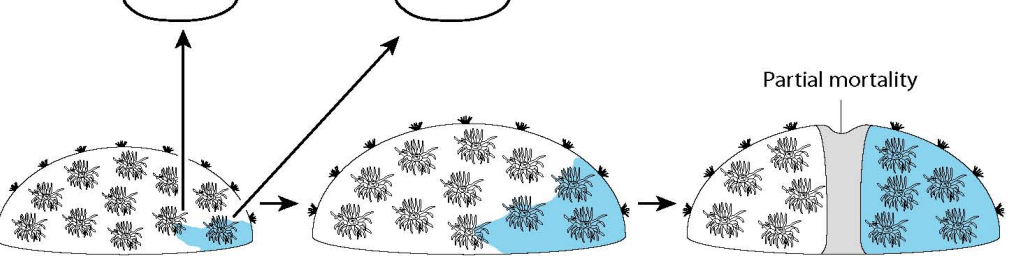

D.

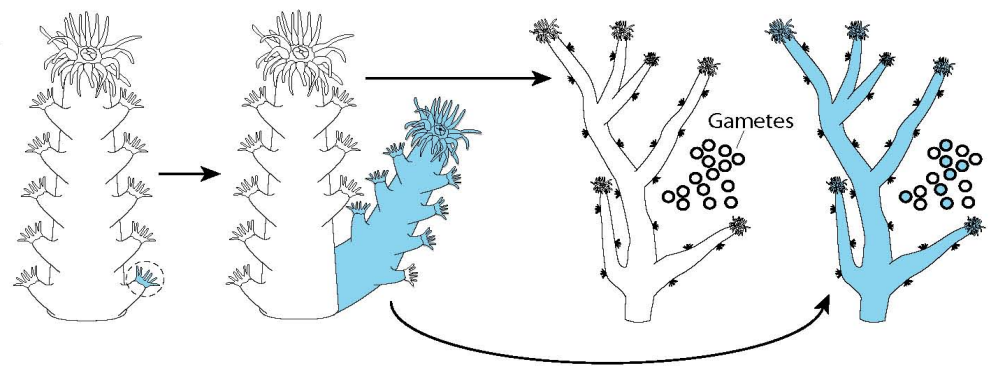




\section{Are Somatic Mutations Fuel for Adaptation of Corals?}

The evidence summarized above from a wide range of partially or fully asexual organisms, indicates that evolution through somatic mutations and cell lineage selection in corals and associated Symbiodinium is likely to be an important mechanism for adaptation to climate change. Figure 4A-D show corals in situ displaying intra-colony phenotypic variation. We hypothesize that such variation may in some instances reflect mosaicism within the host and/or genetic diversity within its associated Symbiodinium population, but this remains to be tested. Based on measurements from a coral population of Acropora millepora in the southern Great Barrier Reef (GBR), we estimate that $\sim 100$ million somatic mutations arise within a single coral colony with a diameter of $30 \mathrm{~cm}$ (Table 1). A $30 \mathrm{~cm}$ A. millepora colony contains approximately half a million polyps, each of which spawns on average 5 eggs [91] and a vast number of sperm cells every spawning event, hence, there is considerable potential for somatic mutations to be passed on to the next sexual generation (Figure 3D). Further, somatic mutations may be passed on to asexually produced larvae or to other polyps and colony fragments (Figure 3A-D). The majority of spontaneous mutations, however, is likely to be selectively neutral, i.e., has no impact on the phenotype or fitness, and the persistence of cells carrying a non-neutral (i.e., under negative or positive selection) mutation will depend on the strength of selection for that mutation [92]. Nevertheless, estimates of beneficial mutations (i.e., those under positive selection) under extreme experimental stress in unicellular algae are astonishingly high and only 100-10,000 fold smaller than the estimates for all (i.e., neutral and non-neutral) somatic mutations in coral $\left(10^{-5}-10^{-7}\right.$ per cell generation, Table 1). Climate change is predicted to result in an increased frequency of extreme weather events [93], which act as strong selective forces on coral and Symbiodinium populations. Mosaicism within the coral host tissues or genetic diversity within Symbiodinium populations may result in different levels of environmental tolerance across a single coral colony and partial, rather than whole, colony mortality is often observed after severe bleaching events [94,95]. Coral bleaching events reduce in hospite Symbiodinium densities to in some cases as low as $10 \%$ of the pre-bleaching population in coral colonies that survive the stress event $[81,96,97]$. Remaining Symbiodinium cells may represent individuals that resisted bleaching because they were occupying microhabitat refuges (e.g., shaded branches) or they may represent genotypes that are better adapted to the bleaching stressor, e.g., elevated temperature. On repopulating the coral's tissues during recovery, the adapted genotype is likely to spread and increase in numbers. Such shifts have been documented for different Symbiodinium types (some even belonging to different clades) under natural [97] and experimental [15] field conditions following severe bleaching, but may have gone undetected if mutant cells better adapted to heat stress were present within a Symbiodinium type. In addition to extreme events, climate change is expected to cause a gradual and persistent increase in mean seawater temperatures [93] and this is a continuous selective force which will push coral and Symbiodinium populations towards increased thermal tolerance if the potential exists to evolve in that direction. Field observations of reduced impact of thermal stress events on coral communities in recent years compared with earlier thermal stress events of the same or lesser severity, suggest that adaptation may already have occurred on some reefs through selective mortality of the less tolerant (host and/or Symbiodinium) genotypes [98-100]. Whether this involved selection on recently evolved (i.e., mutant) genotypes is, however, unknown. 
Table 1. Estimates of the number of somatic mutations arising in coral and Symbiodinium cells in a median size Acropora millepora colony based on the number of cells within the colony, using data from a small fringing reef in the southern Great Barrier Reef (Miall Island). Cell renewal was not taken into account, because it is not known whether cell renewal takes place in corals. In Hydra, cells are continuously being renewed and each individual cell has a relatively short life span [62]. Hence, our estimate is conservative. Note that we present an estimate of all spontaneous somatic mutations (i.e., the sum of neutral mutations and mutations under positive or negative selection) for the coral host, but an estimate of beneficial and phenotypically observable somatic mutations for Symbiodinium. The reason for this is that the latter is based on estimates for free-living unicellular algae, for which mutation rates have been estimated through laboratory selection experiments under various simulated environmental stress conditions, and mutants were phenotypically identified. Similar estimates are not available for the coral animal.

\begin{tabular}{|c|c|c|}
\hline Attribute & Estimate of variable & Reference \\
\hline Median colony diameter $(\mathrm{cm})$ & 30 & [101] \\
\hline No. branches $/ 30 \mathrm{~cm}$ colony & 400 & [101] \\
\hline Surface area/branch $\left(\mathrm{cm}^{2}\right)$ & 13 & [102] \\
\hline Surface area $/ 30 \mathrm{~cm}$, colony $\left(\mathrm{cm}^{2}\right)$ & $400 \times 13=5200$ & \\
\hline No. Symbiodinium cells $/ \mathrm{cm}^{2}$ & $1.5 \times 10^{6}$ & [103] \\
\hline $\begin{array}{l}\text { No. Symbiodinium } \\
\text { cells } / 30 \mathrm{~cm} \text { colony }\end{array}$ & $1.5 \times 10^{6} \times 5200=7.8 \times 10^{9}$ & \\
\hline Ratio of Symbiodinium/host cells & 0.15 & [103] \\
\hline No. coral host cells $/ 30 \mathrm{~cm}$ colony & $7.8 \times 10^{9} / 0.15=5.2 \times 10^{10}$ & \\
\hline $\begin{array}{l}\text { Coral host somatic mutation rate } \\
\text { per cell generation and genome } \\
\text { (assuming } \sim 2 \times 10^{4} \text { genes in corals) }\end{array}$ & $2 \times 10^{-3}$ & {$[104,105]$} \\
\hline $\begin{array}{l}\text { No. somatic mutations arising in coral } \\
\text { host cells in } 30 \mathrm{~cm} \text { colony }\end{array}$ & $10.4 \times 10^{7} \cong 10^{8}$ & \\
\hline $\begin{array}{l}\text { Symbiodinium beneficial and } \\
\text { phenotypically observable somatic } \\
\text { mutation rate per cell generation }\end{array}$ & $10^{-5}-10^{-7}$ & {$[22,23,48-50]$} \\
\hline $\begin{array}{l}\text { No. beneficial mutant Symbiodinium } \\
\text { cells in } 30 \mathrm{~cm} \text { colony }\end{array}$ & $7.8 \times 10^{2}-7.8 \times 10^{4} \cong 10^{3}-10^{5}$ & \\
\hline
\end{tabular}


Figure 4. Field examples of intra-colony phenotypic variation in reef corals. (A) "Tumour"-like structures (white arrow heads) on a Montipora digitata branch that has not bleached while the main branch has. Photo credit: Andrew Heyward; (B) Patchy bleaching across a Goniopora sp. colony. Photo credit: Emily Howells; (C) Differential expression of coral host pigments across a Hydnophora rigida colony. Photo credit: Ray Berkelmans; and (D) Healthy colony of Lobophyllia hemprichii, showing one severely bleached polyp. Photo credit: Emily Howells.
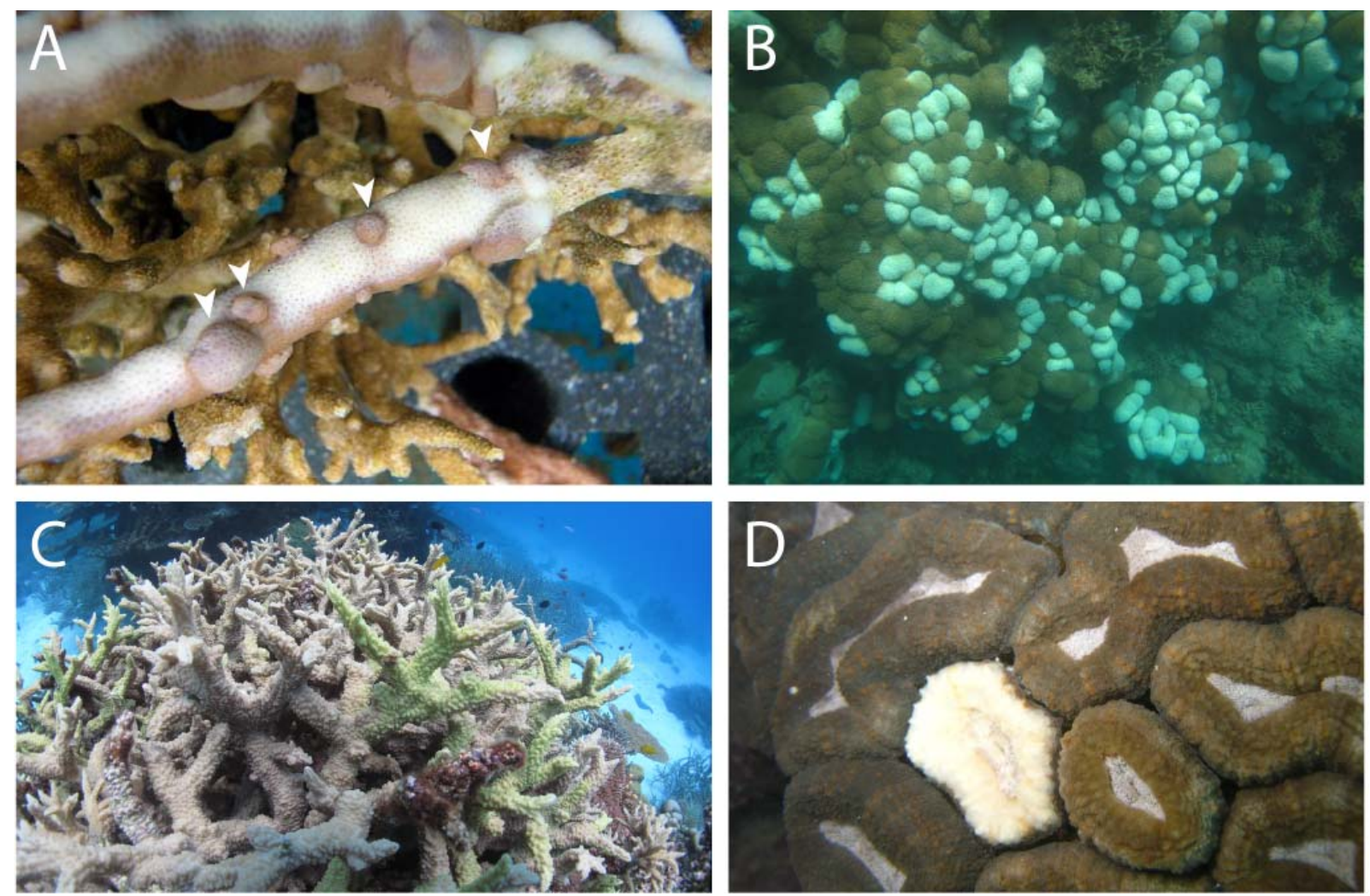

At the population level, the maintenance of genetic diversity is a balance between random genetic drift, migration and natural selection, which either increase or decrease the prevalence of any particular mutation within a population or species [106]. For functional genetic divergence to occur between populations (i.e., local adaptation), the intensity of selection on a certain adaptive trait or beneficial mutation needs to be greater than the combined effects of random genetic drift and migration [107]. The emerging picture on levels of connectivity of both coral hosts and Symbiodinium is that gene flow is relatively restricted for most species of host and symbiont, i.e., that most populations are largely self-seeding [108-110], at least over the time scales relevant to adaptation to climate change impacts. This will facilitate local adaptation as 'dilution' through input of less adapted alleles from outside the population is likely to be low. Drift becomes more important with decreasing effective population sizes $\left(N_{e}\right)$, and low frequency alleles (such as new mutant alleles) have a high probability of being lost in populations with small $N_{e}$. $N_{e}$ values of corals are likely significantly smaller than their census sizes [111,112], because (1) populations are known to greatly fluctuate in size due to a range of perturbations, including crown-of-thorn outbreaks, storms and cyclones, extreme wet seasons and bleaching events [6], (2) fecundity in corals is highly variable [113], (3) asexual reproduction is common in corals [54], and (4) in gonochoric species, sex-ratios may be biased [114]. No estimates of $N_{e}$ 
exist for common species of coral, and the role of drift on the likelihood of a mutant genotype to establish itself within a population is therefore virtually impossible to assess. Other factors that affect the likelihood of a new mutation spreading through a population have been elucidated by a recent model of co-evolutionary interactions between the coral host and associated Symbiodinium [115]. This model predicts that bleaching resistance alleles spread more quickly through the population when bleaching results from death of the coral-Symbiodinium partnership rather than expulsion of Symbiodinium without death, because the death of the partnership is more efficient at removing the disfavoured allele from the coral host and Symbiodinium populations [115]. This finding would extend to partial mortality of tissues with less adapted genotypes within a mosaic colony. The way in which the genomes of the two symbiotic partners interact and the trade-offs between fitness traits (such as thermal tolerance and growth rate) were also found to have a considerable effect on the speed of the spread of resistance alleles. Further, in species that have to acquire Symbiodinium from the environment early in ontogeny (i.e., in the larval or primary polyp stage; $\sim 85 \%$ of all species [64]), the spread of Symbiodinium alleles will be affected by the force and direction of selection in and ex hospite, which need not be the same, and the extent of gene flow between the in hospite and free-living Symbiodinium populations.

\section{Conclusions}

Corals possess a set of attributes that theoretically provides them with considerable adaptive potential through somatic mutations and selection thereon. Many species show extensive asexual reproduction, indeterminate growth, asexual regeneration following partial colony mortality, and longevity, resulting in many mitotic cell divisions and hence, opportunities for somatic mutations to arise within an individual. All coral species lack germ cell lines. Instead, germ cells arise from somatic cells, and therefore, many cell divisions take place prior to the formation of gametes. The model cnidarian, Hydra, is believed to integrate foreign genetic material relatively easily into its genome [116,117], and has been shown to readily accept and incorporate mutant cells into its body [61]. If these traits are also present in corals, they will facilitate cell lineage selection. All reef-building corals form an intimate symbiosis with Symbiodinium, which to a large extent determines the coral's physiological tolerances. Symbiodinium also have attributes that promote adaptation, such as large population sizes and rapid turn-over rates. Baskett et al.'s [118] model of symbiont evolutionary dynamics predicts that some level of adaptation within the following decades is possible in the presence of either genetic or community-level variation in Symbiodinium thermal tolerance, however, these model outcomes have not yet been experimentally validated. We propose that future work should focus on examining the response of Symbiodinium and possibly coral tissues to selection in the laboratory [119]. Recent laboratory selection experiments on 12 unicellular algal species (11 phytoplankton species and Symbiodinium sp.) have shown that adaptation to increased temperatures is possible within 8-150 generations, with the extent of the increase in temperature tolerance and the rate at which adaptation occurred varying among species [120]. Whole genome sequencing of cells/tissues prior to and following the in vitro selection experiment may reveal the mutations responsible for the adaptive response. 


\section{Acknowledgements}

We thank Tim Simmonds (AIMS) for producing Figures 2 and 3. We also thank Bob Buddemeier, Daphne Fautin and two anonymous reviewers for their valuable input into this manuscript.

\section{References}

1. Jansen, E.; Overpeck, J.; Briffa, K.R.; Duplessy, J.-C.; Joos, F.; Masson-Delmotte, V.; Olago, D.; Otto-Bliesner, B.; Peltier, W.R.; Rahmstorf, S.; et al. Contribution of Working Group I to the Fourth Assessment Report of the Intergovernmental Panel on Climate Change. In Climate Change 2007: The Physical Science Basis; Solomon, S., Qin, D., Manning, M., Chen, Z., Marquis, M., Averyt, K.B., Tignor, M., Miller, H.L., Eds.; Cambridge University Press: Cambridge, UK; New York, NY, USA, 2007; pp. 433-497.

2. Anthony, K.R.N.; Maynard, J.A.; Diaz-Pulido, G.; Mumby, P.J.; Marshall, P.; Cao, L.; Hoegh-Guldberg, O. Ocean acidification and warming will lower coral reef resilience. Global Change Biol. 2011, 17, 1798-1808.

3. Anthony, K.R.N.; Kline, D.I.; Diaz-Pulido, G.; Dove, S.; Hoegh-Guldberg, O. Ocean acidification causes bleaching and productivity loss in coral reef builders. Proc. Natl. Acad. Sci. USA 2008, 105, 17442-17446.

4. Gardner, T.A.; Cote, I.M.; Gill, J.A.; Gant, A.; Watkinson, A.R. Long-term region-wide declines in Caribbean corals. Science 2003, 301, 958-960.

5. Bruno, J.F.; Selig, E.R. Regional decline of coral cover in the Indo-Pacific: Timing, extent, and subregional comparisons. PLoS One 2007, 2, e711.

6. Sweatman, H.; Delean, S.; Syms, C. Assessing loss of coral cover on Australia's Great Barrier Reef over two decades, with implications for longer-term trends. Coral Reefs 2011, 30, 521-531.

7. Wilkinson, C. Status of the Coral Reefs of the World: 2008; Global Coral Reef Monitoring Network and Reef and Rainforest Research Centre: Townsville, Australia, 2008; p. 296.

8. Hoegh-Guldberg, O.; Mumby, P.J.; Hooten, A.J.; Steneck, R.S.; Greenfield, P.; Gomez, E.; Harvell, C.D.; Sale, P.F.; Edwards, A.J.; Caldeira, K.; et al. Coral reefs under rapid climate change and ocean acidification. Science 2007, 318, 1737-1742.

9. Hoegh-Guldberg, O. Climate change, coral bleaching and the future of the world's coral reefs. Mar. Freshwater Res. 1999, 50, 839-866.

10. Baird, A.H.; Bhagooli, R.; Ralph, P.J.; Takahashi, S. Coral bleaching: The role of the host. Trends Ecol. Evol. 2009, 24, 16-20.

11. Maynard, J.A.; Baird, A.H.; Pratchett, M.S. Revisiting the Cassandra syndrome; The changing climate of coral reef research. Coral Reefs 2008, 27, 745-749.

12. Babcock, R.C. Comparative demography of 3 species of scleractinain corals using age-dependent and size-dependent classifications. Monographs 1991, 61, 225-244.

13. Omori, M. Degradation and restoration of coral reefs: Experience in Okinawa, Japan. Mar. Biol. Res. 2010, 7, 3-12. 
14. Mieog, J.C.; Olsen, J.L.; Berkelmans, R.; Bleuler-Martinez, S.A.; Willis, B.L.; van Oppen, M.J.H. The roles and interactions of symbiont, host and environment in defining coral fitness. PLoS One 2009, 4, e6364.

15. Berkelmans, R.; van Oppen, M.J.H. The role of zooxanthellae in the thermal tolerance of corals: A 'nugget of hope' for coral reefs in an era of climate change. Proc. R. Soc. London B 2006, 273, 2305-2312.

16. Abrego, D.; Ulstrup, K.E.; Willis, B.L.; van Oppen, M.J.H. Species-specific interactions between algal endosymbionts and coral hosts define their bleaching response to heat and light stress. Proc. R. Soc. B 2008, 275, 2273-2282.

17. Rowan, R. Thermal adaptation in reef coral symbionts. Nature 2004, 430, 742.

18. Santos, S.R.; Coffroth, M.A. Molecular genetic evidence that dinoflagellates belonging to the genus Symbiodinium Freudenthal are haploid. Biol. Bull. 2003, 204, 111-120.

19. Blank, R.J. Cell architecture of the dinoflagellate Symbiodinium sp. inhabiting the Hawaiian stony coral Montipora verrucosa. Mar. Biol. 1987, 94, 143-155.

20. Correa, A.M.S.; Baker, A.C. Understanding diversity in coral-algal symbiosis: A cluster-based approach to interpreting fine-scale genetic variation in the genus Symbiodinium. Coral Reefs 2009, 28, 81-93.

21. Santos, S.R.; Gutierrez-Rodriguez, C.; Lasker, H.R.; Coffroth, M.A. Symbiodinium sp. associations in the gorgonian Pseudopterogorgia elisabethae in the Bahamas: High levels of genetic variability and population structure in symbiotic dinoflagellates. Mar. Biol. 2003, 143, 111-120.

22. Baos, R.; Garcia-Villada, L.; Agrelo, M.; Lopez-Rodas, V.; Hiraldo, F.; Costas, E. Short-term adaptation of microalgae in highly stressful environments: An experimental model analysing the resistance of Scenedesmus intermedius (Chlorophyceae) to the heavy metals mixture from the Aznalcollar mine spill. Eur. J. Phycol. 2002, 37, 593-600.

23. Costas, E.; Flores-Moya, A.; Perdigones, N.; Maneiro, E.; Blanco, J.L.; Garcia, M.E.; Lopez-Rodas, V. How eukaryotic algae can adapt to the Spain's Rio Tinto: A neo-Darwinian proposal for rapid adaptation to an extremely hostile ecosystem. New Phytol. 2007, 175, 334-339.

24. Correa, A.M.S.; Baker, A. Disaster taxa in microbially mediated metazoans: How endosymbionts and environmental catastrophes influence the adaptive capacity of reef corals. Global Change Biol. 2011, 17, 68-75.

25. Fautin, D.G. Cnidarian Reproduction: Assumptions and their implications. In Coelenterate Biology: Proceedings of the Sixth International Congress of Coelenterate Biology; Nationaal Natuurhistorisch Museum: Leiden, The Netherlands, 1997; pp. 151-162.

26. Buddemeier, R.W.; Fautin, D.G.; Ware, J.R. Acclimation, adaptation and algal symbioses in reef-building scleractinian corals. In Proceedings of the 6th International Conference on Coelenterate Biology, Noordwijkerhout, The Netherlands, 16-21 July 1995; pp. 71-76.

27. Lynch, M. Evolution of the mutation rate. Trends Genet. 2010, 26, 345-352.

28. Buss, L.W. Evolution, development, and the units of selection. Proc. Natl. Acad. Sci. USA 1983, 80, 1387-1391.

29. Crow, J.F. How much do we know about spontaneous human mutation-rates? Environ. Mol. Mutagen. 1993, 21, 122-129. 
30. Rinkevich, B.; Matranga, V. Stem Cells in Marine Organisms; Springer: Dordrecht, The Netherlands, 2009.

31. Lushai, G.; Loxdale, H.D.; Allen, J.A. The dynamic clonal genome and its adaptive potential. Biol. J. Linn. Soc. 2003, 79, 193-208.

32. Monro, K.; Poore, A.G.B. Selection in modular organisms: Is intraclonal variation in macroalgae evolutionarily important? Am. Nat. 2004, 163, 564-578.

33. Fagerstrom, T.; Briscoe, D.A.; Sunnucks, P. Evolution of mitotic cell-lineages in multicellular organisms. Trends Ecol. Evol. 1998, 13, 117-120.

34. Pineda-Krch, M.; Fagerstrom, T. On the potential for evolutionary change in meristematic cell lineages through intraorganismal selection. J. Evol. Biol. 1999, 12, 681-688.

35. Monro, K.; Poore, A.G.B. The potential for evolutionary responses to cell-lineage selection on growth form and its plasticity in a red seaweed. Am. Nat. 2009, 173, 151-163.

36. Gill, D.E.; Chao, L.; Perkins, S.L.; Wolf, J.B. Genetic mosaicism in plants and clonal animals. Annu. Rev. Ecol. Syst. 1995, 26, 423-444.

37. Butlin, R.; Schon, I.; Martens, K. Asexual reproduction in nonmarine ostracods. Heredity 1998, 81, 473-480.

38. Perez, M.L.; Valverde, J.R.; Batuecas, B.; Amat, F.; Marco, R.; Garesse, R. Speciation in the Artemia genus-mitochindrial-DNA analysis of bisexual and parthenogenetic brine shrimps. J. Mol. Evol. 1994, 38, 156-168.

39. Welch, D.B.M.; Meselson, M. Oocyte nuclear DNA content and GC proportion in rotifers of the anciently asexual Class Bdelloidea. Biol. J. Linn. Soc. 2003, 79, 85-91.

40. Welch, D.B.M.; Meselson, M. Evidence for the evolution of bdelloid rotifers without sexual reproduction or genetic exchange. Science 2000, 288, 1211-1215.

41. Normark, B.B. Phylogeny and evolution of parthenogenetic weevils of the Aramigus tessellatus species complex (Coleoptera: Curculionidae: Naupactini): Evidence from mitochondrial DNA sequences. Evolution 1996, 50, 734-745.

42. Hedges, S.B.; Bogart, J.P.; Maxson, L.R. Ancestry of unisexual salamanders. Nature 1992, 356, 708-710.

43. Loxdale, H.D.; Lushai, G. Rapid changes in clonal lines: The death of a 'sacred cow'. Biol. J. Linn. Soc. 2003, 79, 3-16.

44. Bunting, S.; van Emden, H.F. Rapid response to selection for increased esterease-activity on small populations of an apomictic clone of Myzus-persicae. Nature 1980, 285, 502-503.

45. Ally, D.; Ritland, K.; Otto, S.P. Can clone size serve as a proxy for clone age? An exploration using microsatellite divergence in Populus tremuloides. Mol. Ecol. 2008, 17, 4897-4911.

46. Schnittler, M.; Eusemann, P. Consequences of genotyping errors for estimation of clonality: A case study on Populus euphratica Oliv. (Salicaceae). Evol. Ecol. 2010, 24, 1417-1432.

47. Flores-Moya, A.; Costas, E.; Lopez-Rodas, V. Roles of adaptation, chance and history in the evolution of the dinoflagellate Prorocentrum triestinum. Naturwissenschaften 2008, 95, 697-703. 
48. Garcia-Villada, L.; Lopez-Rodas, V.; Banares-Espana, E.; Flores-Moya, A.; Agrelo, M.; Martin-Otero, L.; Costas, E. Evolution of microalgae in highly stressing environments: An experimental model analyzing the rapid adaptation of Dictyosphaerium chlorelloides (Chlorophyceae) from sensitivity to resistance against 2,4,6-trinitrotoluene by rare preselective mutations. J. Phycol. 2002, 38, 1074-1081.

49. Lopez-Rodas, V.; Costas, E.; Maneiro, E.; Marva, F.; Rouco, M.; Delgado, A.; Flores-Moya, A. Living in Vulcan's forge: Algal adaptation to stressful geothermal ponds on Vulcano Island (southern Italy) as a result of pre-selective mutations. Phycol. Res. 2009, 57, 111-117.

50. Lopez-Rodas, V.; Marva, F.; Rouco, M.; Costas, E.; Flores-Moya, A. Adaptation of the chlorophycean Dictyosphaerium chlorelloides to stressful acidic, mine metal-rich waters as result of pre-selective mutations. Chemosphere 2008, 5, 703-707.

51. Wells, J.W. Scleractinia. In Treatise on Invertebrate Palaeontology; Moore, R.C., Ed.; Geological Society of America: Boulder, CO, USA, 1956; pp. 328-444.

52. Cairns, S.D. Asexual Reproduction in Solitary Scleractinia. In Proceedings of the 6th International Coral Reef Symposium, Townsville, Australia, 8-12 August 1988; Volume 2, pp. 641-646.

53. Borneman, E.H. Reproduction in aquarium corals. In Proceedings of the 10th International Coral Reef Symposium, Okinawa, Japan, 28 June-2 July 2004; pp. 50-60.

54. Harrison, P.L. Sexual reproduction of scleractinian corals. In Coral Reefs: An Ecosystem in Transition, 1st ed.; Dubinsky, Z., Stambler, N., Eds.; Springer Science+Business Media, B.V.: Dordrecht, The Nehterlands, 2011; pp. 59-85.

55. Sammarco, P.W. Polyp bail-out: An escape response to environmental stress and a new means of reproduction in corals. Mar. Ecol. Prog. Ser. 1982, 10, 57-65.

56. Highsmith, R.C. Reproduction by fragmentation in corals. Mar. Ecol. Prog. Ser. 1982, 7, 207-226.

57. Kramarsky-Winter, E.; Fine, M.; Loya, Y. Coral polyp expulsion. Nature 1997, 387, 137-137.

58. Rosen, B.R.; Taylor, J.D. Reef coral from Aldabra: New mode of reproduction. Science 1969, 166, 119-121.

59. O’Connell, L.M.; Ritland, K. Somatic mutations at microsatellite loci in western redcedar (Thuja plicata: Cupressaceae). J. Hered. 2004, 95, 172-176.

60. Tannreuther, G.W. Budding in Hydra. Biol. Bull. 1909, 16, 210-214.

61. Wittlieb, J.; Khalturin, K.; Lohmann, J.U.; Anton-Erxleben, F.; Bosch, T.C.G. Transgenic Hydra allow in vivo tracking of individual stem cells during morphogenesis. Proc. Natl. Acad. Sci. USA 2006, 103, 6208-6211.

62. Bosch, T.C.G. Hydra and the evolution of stem cells. BioEssays 2009, 31, 478-486.

63. Kenyon, J.C. Models of reticulate evolution in the coral genus Acropora based on chromosome numbers: Parallels with plants. Evolution 1997, 51, 756-767.

64. Richmond, R.H. Reproduction and recruitment in corals: critical links in the persistence of reefs. In Life and Death of Coral Reefs, 1st ed.; Birkeland, C., Ed.; Chapman \& Hall: New York, NY, USA, 1997; pp. 175-197.

65. Drew, E.A. The biology and physiology of alga invertebrate symbioses part 2: The density of symbiotic algal cells in a number of hermatypic hard corals and alcyonarians from various depths. J. Exp. Mar. Biol. Ecol. 1972, 9, 71-75. 
66. Kawaguti, S.; Nakayama, T. Population densities of zooxanthellae in reef corals. Biol. J. Okayama Univ. 1973, 16, 67-71.

67. Dustan, P. Distribution of zooxanthellae and photosynthetic chloroplast pigments of the reef building coral Montastrea-annularis in relation to depth on a West-Indian coral reef. Bull. Mar. Sci. 1979, 29, 79-95.

68. Falkowski, P.G.; Dubinsky, Z. Light shade adaptation of Stylophora-pistillata, a hermatypic coral from the Gulf of Eilat, Aqaba, Red Sea. Nature 1981, 289, 172-174.

69. McCloskey, L.R.; Muscatine, L. Production and respiration in the Red Sea coral Stylophora pistillata as a function of depth. Proc. R. Soc. London B 1984, 222, 215-230.

70. Stimson, J. The annual cycle of density of zooxanthellae in the tissues of field and laboratory-held Pocillopora damicornis (Linnaeus). J. Exp. Mar. Biol. Ecol. 1997, 214, 35-48.

71. Fagoonee, I.; Wilson, H.B.; Hassell, M.P.; Turner, J.R. The dynamics of zooxanthellae populations: A long-term study in the field. Science 1999, 283, 843-845.

72. Coffroth, M.A.; Santos, S.R. Genetic diversity of symbiotic dinoflagellates in the genus Symbiodinium. Protist 2005, 156, 19-34.

73. Littman, R.A.; van Oppen, M.J.H.; Willis, B.L. Methods for sampling free-living Symbiodinium (zooxanthellae) and their distribution and abundance at Lizard Island (Great Barrier Reef). J. Exp. Mar. Biol. Ecol. 2008, 364, 48-53.

74. Porto, I.; Granados, C.; Restrepo, J.C.; Sanchez, J.A. Macroalgal-associated dinoflagellates belonging to the genus Symbiodinium in Caribbean reefs. PLoS One 2008, 3, e2160.

75. Venera-Ponton, D.E.; Diaz-Pulido, G.; Rodriguez-Lanetty, M.; Hoegh-Guldberg, O. Presence of Symbiodinium spp. in macroalgal microhabitats from the southern Great Barrier Reef. Coral Reefs 2010, 29, 1049-1060.

76. LaJeunesse, T.C. Investigating the biodiversity, ecology, and phylogeny of endosymbiotic dinoflagellates in the genus Symbiodinium using the ITS region: In search of a "species" level marker. J. Phycol. 2001, 37, 866-880.

77. Muscatine, L.; Falkowski, P.G.; Porter, J.W.; Dubinsky, Z. Fate of photosynthetic fixed carbon in light- and shade-adpated colonies of the symbiotic coral Stylophora pistillata. Proc. R. Soc. London B 1984, 222, 181-202.

78. Hoegh-Guldberg, O.; McCloskey, L.R.; Muscatine, L. Expulsion of zooxanthellae by symbiotic cnidarians from the Red Sea. Coral Reefs 1987, 5, 201-204.

79. Wilkerson, F.P.; Kobayashi, D.; Muscatine, L. Mitotic index and size of symbiotic algae in Caribbean reef corals. Coral Reefs 1988, 7, 29-36.

80. Fitt, W.K.; Spero, H.J.; Halas, J.; White, M.W.; Porter, J.W. Recovery of the coral Montastrea annularis in the Florida Keys after the 1987 Caribbean "bleaching event". Coral Reefs 1993, 12, 57-64.

81. Jones, R.J.; Yellowlees, D. Regulation and control of intracellular algae (equals zooxanthellae) in hard corals. Philos. Trans. R. Soc. London B 1997, 352, 457-468.

82. Stat, M.; Morris, E.; Gates, R.D. Functional diversity in coral-dinoflagellate symbiosis. Proc. Natl. Acad. Sci. USA 2008, 105, 9256-9261.

83. Cantin, N.E.; van Oppen, M.J.H.; Willis, B.L.; Mieog, J.C.; Negri, A.P. Juvenile corals can acquire more carbon from high-performance algal symbionts. Coral Reefs 2009, 28, 405-414. 
84. Cook, C.B.; D'Elia, C.F.; Muller-Parker, G. Host feeding and nutrient sufficiency for zooxanthellae in the sea anemone Aiptasia-pallida. Mar. Biol. 1988, 98, 253-262.

85. Titlyanov, E.A.; Titlyanova, T.V.; Leletkin, V.A.; Tsukahara, J.; van Woesik, R.; Yamazato, K. Degradation of zooxanthellae and regulation of their density in hermatypic corals. Mar. Ecol. Prog. Ser. 1996, 139, 167-178.

86. Muscatine, L.; Pool, R.R. Regulation of numbers of intra-cellular algae. Proc. R. Soc. London B 1979, 204, 131-139.

87. Kinzie, R.A., III; Takayama, M.; Santos, S.R.; Coffroth, M.A. The adaptive bleaching hypothesis: Experimental tests of critical assumptions. Biol. Bull. 2001, 200, 51-58.

88. Taguchi, S.; Kinzie, R.A., III. Growth of zooxanthellae in culture with two nitrogen sources. Mar. Biol. 2001, 138, 149-155.

89. Fitt, W.K.; Trench, R.K. Relation of diel patterns of cell division to diel patterns of motility in the symbiotic dinoflagellate Symbiodinium-microadriaticum in culture. New Phytol. 1983, 94, 421-432.

90. Purkis, S.J.; Renegar, D.A.; Riegl, B.M. The most temperature-adapted corals have an Achilles' Heel. Mar. Pollut. Bull. 2011, 62, 246-250.

91. Hall, V.R.; Hughes, T.P. Reproductive strategies of modular organisms: Comparative studies of reef-building corals. Ecology 1996, 77, 950-963.

92. Otto, S.P.; Hastings, I.M. Mutation and selection within the individual. Genetica 1998, 102-103, 507-524.

93. Allison, I.; Bindoff, N.L.; Bindschadler, R.A.; Cox, P.M.; de Noblet, N.; England, M.H.; Francis, J.E.; Gruber, N.; Haywood, A.M.; Karoly, D.J.; et al. The Copenhagen Diagnosis, 2009: Updating the world on the Latest Climate Science; The University of New South Wales Climate Change Research Centre (CCRC): Sydney, Australia, 2009; p. 60.

94. Jones, R.J. Coral bleaching, bleaching-induced mortality, and the adaptive significance of the bleaching response. Mar. Biol. 2008, 154, 65-80.

95. Montano, S.; Seveso, D.; Galli, P.; Obura, D.O. Assessing coral bleaching and recovery with a colour reference card in Watamu Marine Park, Kenya. Hydrobiologia 2010, 655, 99-108.

96. Hoegh-Guldberg, O.; McCloskey, L.R.; Muscatine, L. Expulsion of zooxanthellae by symbiotic cnidatians from the Red-Sea. Coral Reefs 1987, 5, 201-204

97. Jones, A.M.; Berkelmans, R.; van Oppen, M.J.H.; Mieog, J.C.; Sinclair, W. A community change in the algal endosymbionts of a scleractinian coral following a natural bleaching event: Field evidence of acclimatization. Proc. R. Soc. B 2008, 275, 1359-1365.

98. Maynard, J.A.; Anthony, K.R.N.; Marshall, P.A.; Masiri, I. Major bleaching events can lead to increased thermal tolerance in corals. Mar. Biol. 2008, 155, 173-182.

99. Berkelmans, R. Bleaching and Mortality Thresholds: How much is too much? In Coral Bleaching: Patterns, Processes, Causes and Consequences; van Oppen, M.J.H., Lough, J.M., Eds.; Ecological Studies, Springer-Verlag: Berlin, Heidelberg, German, 2009; pp. 103-119.

100. Thompson, D.M.; van Woesik, R. Corals escape bleaching in regions that recently and historically experienced frequent thermal stress. Proc. R. Soc. B 2009, 276, 2893-2901.

101. Puill-Stephan. E. State of Acropora millepora in the Keppel Islands (August 2006); Report to the Great Barrier Reef Marine Park Authority, 2006. 
102. Berkelmans, R. Unpublished data.

103. Mieog, J.C.; van Oppen, M.J.H.; Berkelmans, R.; Stam, W.T.; Olsen, J.L. Quantification of algal endosymbionts (Symbiodinium) in coral tissue using real-time PCR. Mol. Ecol. Resour. 2009, 9, 74-82.

104. Technau, U.; Rudd, S.; Maxwell, P.; Gordon, P.M.K.; Saina, M.; Grasso, L.C.; Hayward, D.C.; Sensen, C.W.; Saint, R.; Holstein, T.W.; et al. Maintenance of ancestral complexity and non-metazoan genes in two basal cnidarians. Trends Genet. 2005, 21, 633-639.

105. Orive, M.E. Somatic mutations in organisms with complex life histories. Theor. Popul. Biol. 2001, 59, 235-249.

106. Hartl, D.L.; Clark, A.G. Principles of Population Genetics, 3rd ed.; Sinauer Associates Inc: Sunderland, MA, USA, 1997; p. 542.

107. Beaumont, M.A.; Balding, D.J. Identifying adaptive genetic divergence among populations from genome scans. Mol. Ecol. 2004, 13, 969-980.

108. Kirk, N.L.; Andras, J.P.; Harvell, C.D.; Santos, S.R.; Coffroth, M.A. Population structure of Symbiodinium sp. associated with the common sea fan, Gorgonia ventalina, in the Florida Keys across distance, depth, and time. Mar. Biol. 2009, 156, 1609-1623.

109. Jones, G.P.; Almany, G.R.; Russ, G.R.; Sale, P.F.; Steneck, R.S.; van Oppen, M.J.H.; Willis, B.L. Larval retention and connectivity among populations of corals and reef fishes: History, advances and challenges. Coral Reefs 2009, 28, 307-325.

110. Howells, E.J.; van Oppen, M.J.H.; Willis, B.L. High genetic differentiation and cross-shelf patterns of genetic diversity among Great Barrier Reef populations of Symbiodinium. Coral Reefs 2009, 28, 215-225.

111. Hughes, T.P.; Ayre, D.J.; Connell, J.H. The evolutionary ecology of corals. Trends Ecol. Evol. 1992, 7, 292-295.

112. Frankham, R. Effective population-size, adult-population size ratios in wildlife-A review. Genet. Res. 1995, 66, 95-107.

113. Wallace, C.C. Reproduction, recruitment and fragmentation in nine sympatric species of the coral genus Acropora. Mar. Biol. 1985, 88, 217-233.

114. Loya, Y.; Sakai, K. Bidirectional sex change in mushroom stony corals. Proc. R. Soc. B 2008, 275, 2335-2343.

115. Day, T.; Nagel, L.; van Oppen, M.J.H.; Caley, M.J. Factors affecting the evolution of bleaching resistance in corals. Am. Nat. 2008, 171, E72-E88.

116. Habetha, M.; Bosch, T.C.G. Symbiotic Hydra express a plant-like peroxidase gene during oogenesis. J. Exp. Biol. 2005, 208, 2157-2164.

117. Steele, R.E.; Hampson, S.E.; Stover, N.A.; Kibler, D.F.; Bode, H.R. Probable horizontal transfer of a gene between a protist and a cnidarian. Curr. Biol. 2004, 14, R298-R299.

118. Baskett, M.L.; Gaines, S.D.; Nisbet, R.M. Symbiont diversity may help coral reefs survive moderate climate change. Ecol. Appl. 2009, 19, 3-17.

119. Huertas, I.E.; Rouco, M.; Lopez-Rodas, V.; Costas, E. Estimating the capability of different phytoplankton groups to adapt to contamination: Herbicides will affect phytoplankton species differently. New Phytol. 2010, 188, 478-487. 
120. Huertas, I.E.R.; Lopez-Rodas, V.; Costas, E. Warming will affect phytoplankton differently: Evidence through a mechanistic approach. Proc. R. Soc. B 2011, doi:10.1098/rspb.2011.0160.

(C) 2011 by the authors; licensee MDPI, Basel, Switzerland. This article is an open access article distributed under the terms and conditions of the Creative Commons Attribution license (http://creativecommons.org/licenses/by/3.0/). 